\title{
EFL Learners' View on Online Learning Implementation During Covid-19 Outbreaks
}

\author{
Melvina ${ }^{13 *}$, Nenden Sri Lengkanawati ${ }^{1}$, Yanty Wirza ${ }^{1}$, Dona $_{\text {Alicia }}^{2}$, Yulmiati $^{3}$ \\ ${ }^{1}$ English Language Education Department, Universitas Pendidikan Indonesia, Bandung, Indonesial * \\ ${ }^{2}$ English language and literature, Khazar University, Azerbaijan \\ ${ }^{3}$ English Language Education Department, STKIP PGRI Sumatera Barat, Padang \\ *Corresponding author. Email: melvina@upi.edu
}

\begin{abstract}
During the Covid-19 outbreaks, the teaching and learning practice in Indonesia has been implemented in online setting to prevent the spread of the disease, and study from home using digital technology as promoted in Education 4.0 became a burning issue. The mainly purpose of the study is to investigate the views of Indonesian undergraduate EFL learners in online learning implementation during the Covid-19 outbreaks. Data were collected through online interview, involving 6 participants and analysed by using thematic analysis. The findings of the study revealed that Indonesian undergraduate EFL students consciously realize that study from home and using online learning is the best way during covid-19 outbreaks. Also, they reported that they faced several obstacles to online learning during the pandemic such as lack of knowledge and skills in online learning, unstable internet connection, and the teachers' limited experience with online learning. Besides, the findings of the study revealed that implementing online learning contributes more on students' learner autonomy. The results of the current study are hoped can stimulate further discussion in order to overcome online learning barriers by considering the importance of learners' voice.
\end{abstract}

Keywords: Covid-19 outbreaks, Digital technology, Learner autonomy, Online learning, Undergraduate EFL students.

\section{INTRODUCTION}

In Indonesia, the government has declared Covid-19 a global pandemic and directly restricted the mobilization of community as an effort to prevent the spread of the disease on March 12th, 2020. Then, the agenda of work and study from home has been promoted. Consequently, since March 14th, 2020 the schools and universities have been temporarily closed. The teaching and learning process have been shifted to the use of digital technologies during the outbreak.

To be specific, the teaching practices today especially during the Covid-19 outbreak, encouraged teachers and students to turn to online learning or conduct online classes from home utilizing the relevant technology tools. It means that everything is online, such as online task, online presentation, online assignment, and online assessment [1], [2], [3]. However, in implementing online learning during pandemic is not always effective [4], [5]]. Particularly for university that have limited experience with online learning. Moreover, it becomes complicated when teachers do not familiar with learning system using online applications.

Some of the previous research have been discussed about implementing online learning during covid-19 outbreak. Rajab, Gazal, \& Alkattan [6] conducted a cross-sectional study to analyze the impact of the COVID-19 pandemic on online education at the College of Medicine (COM) of Alfaisal University in Riyadh, Saudi Arabia. The results showed that there has been a positive impact of the COVID-19 pandemic on online medical education at Alfaisal University. Meanwhile, the challenges appeared including communication, student assessment, use of technology tools, online experience, pandemic-related anxiety or stress, time management, and technophobia. The study by Babayiğit, Cizrelioğullari, \& Altun [2] aims to seek 
students' views towards the employment of online learning tools for teaching. Three hundred university students of Turkish, Kurdish, and Arab who was taking online learning course were invited to answer the questionnaire consisting of 10 items. The study revealed that there have been both positive and negative attitudes towards online learning by students. Dhawan [7] conducted a systematic review to describe the importance of online learning and Strengths, Weaknesses, Opportunities, \& Challenges (SWOC) analysis of e-learning modes in the time of pandemic. A study conducted by Adnan \& Anwar [8] to examine the undergraduate and postgraduate students' perspectives about online learning amid the COVID-19 pandemic in Pakistan. The findings showed that online learning produces undesired results in underdeveloped countries like Pakistan.

With reference to Indonesian context, there is limited study on online learning implementation in the time of Covid-19 outbreak. Rasmitadila et al., [9] conducted a case study to explore the perceptions of primary school teachers of online learning as an impact of school from home during the COVID-19 Pandemic in Indonesia. The study by Almanthari, Maulina \& Bruce [1] aims to examine the views of secondary school mathematics teachers on E-learning implementation barriers during the COVID-19 pandemic. Irfan, Kusumaningrum, Yulia, \& Widodo [10] conducted a study to determine the obstacles that arise after online learning in mathematics learning has been implemented in higher education. A study conducted by Famularsih [11] focuses on the utilization of online learning application in English as a Foreign Language (EFL) Classroom.

Based on the previous studies, the majority of research on online-learning implementation were conducted did not focus on English language teaching. Accordingly, we conducted a research to know the EFL students' views towards the implementation of online learning during Covid-19 outbreaks in Indonesia.

More specifically, this study focused on the undergraduate EFL students in Indonesia to investigate the following questions: 1) what are the students' view toward the implementation of online learning during Covid-19 outbreaks, 2) what are the challenging faced by students in the implementation of online learning during the Covid-19 outbreaks, and 3) what are the benefits of the implementation of online learning during the Covid-19 outbreaks towards students' English language learning.

\subsection{Online Teaching and Learning during Covid-19 Outbreaks}

Over the past decade, online courses have grown fast [12-15]. Due to the need to maintain competition and make classrooms more accessible to growing students and diverse student populations, a number of colleges and universities across the United States are shifting traditional face-to-face teaching to fully online [13]. Further, he also reported undergraduate students preferred online courses to the traditional classes because they learned more and spent significantly more time in online classes. Even though these classes were more challenging, but they believed online classes had higher quality than face-to-face classes [16], [17]. Additionally, online teaching offers new and exciting experiences in learning for diverse students [13], provides innovative educational opportunities for students who have time management problems in their learning strategies, with low anxiety, and high problem solving efficacy [18], develops metacognitive, reflective, and collaborative learning [19].

According to Dhawan [7], online learning is a learning experience in synchronous or asynchronous settings using different devices such as mobile phones, laptops, etc. with internet access. In the synchronous learning setting, students attend live lectures, have realtime interactions with lectures, and can get feedback directly. Whereas, in the asynchronous setting learning process available in different places and time and it makes instant feedback, as well as an immediate response, is not possible. Further, Dhawan [7] explains that online learning can make the teaching-learning process more student centred in which students can learn anytime and anywhere, schedule or plan their time in completing the course, increase their learning potential and develop new skills for life-long learning.

In this time of the pandemic, the use of the Information, communication, and technology (ICT) in teaching and learning during pandemic cannot be avoided. Moreover, we are facing Education 4.0 right now. Education 4.0 requires both teachers and students to use more digital technology in language learning [20]. Before pandemic, mostly students in Indonesia use internet frequently to access learning material and information. They also use it to share their knowledge in online forum discussion. Today, they are engaged to study fully online while still socializing with classmates, watching lectures, and participating in subject-specific discussions. It can be concluded that the Covid-19 pandemic forced almost all universities in the world to change their teaching and learning process to online methods [4], [21], [22], [23], including Indonesia.

Online learning is considered as a good choice to continue the teaching and learning process during the pandemic because it can eliminate distance and time with the help of internet-based digital platforms. Accordingly, it greatly helps the learning process without any physical interaction [24].

However, implementing online learning is not easy as we think. It needs skills to run it smoothly and 
effectively. To implement online learning, a university or school should be ready and prepare everything; especially teachers should have experience in online learning [5]. According to some research results (e.g., [1--25] several obstacles arise in online learning is that many teachers still do not understand how to apply it and unstable internet connection because it is used simultaneously.

There are several problems associated with modern technology in online teaching including downloading errors, installation issues, problems to log in, and audio and video problems [7]. Besides, students sometimes find online teaching is boring and unengaging. Since they have much time and flexibility, they hard to find time to study or completing tasks.

Several common problems encountered by the teachers when using e-learning include lack of time to prepare a lesson, lack of adequate professional development concerning technology, limited facilities, and lack of technical supports [26]. Similarly, it was found that lack of time to develop e-course is the most significant barrier, followed by infrastructure and technology while lack of students' ICT skills is the least significant barrier [27].

E-learning barriers were classified into learners, teachers, curriculum, and schools [28]. The learner barriers include financial problems, motivation, and assessment of progress, isolation from peers, inadequate skills, and experience in online learning, affection, and social domain. The teacher barriers comprise of lack of adequate knowledge about e-learning and difficulty for assessment. The curriculum barriers consist of ambiguity, quality, resource, teaching process, and evaluation. The school barriers refer to organizational and structural factors.

\section{METHOD}

The study used a qualitative method to collect and analyse the data obtained from all the participants. Qualitative research is based on descriptive data and it does not require the statistical process [29].

The total of participants of this study were six Indonesian undergraduate EFL students consisting of four females and two males studying at a state university in Bandung, Indonesia. They were selected based on their availability.

The data of the study were collected using online interview as it was easy to be conducted and accessed using various devices [30]. The researchers used voice note of WhatsApp to interview the subjects of the research because it was easy and practical. It also did not require any special skills to operate. Then, the responses from the interviewee appear in real time and automatically saved in the internal memory of smart phone. More importantly it is believed to be effective in collecting data during Covid-19 outbreak. The online interview was held on June, 16th-18th 2020.

To analyse the data from interview, the researchers adopted thematic analysis. Thematic analysis is a technique to identify, analyse, organize, describe, and report themes within a data set [31]. The process of thematic analysis is familiarizing the researcher with the data, generating initial codes, searching for themes, reviewing themes, defining and naming themes, and producing the report. In initial analysis, the researcher transcribed the voice-noted data into written ones [29]. To ensure the reliability of the data, a colleague of the researchers was invited to check the transcriptions of the data with the researchers. Then, the transcribed data was categorized according to the research questions.

\section{RESULTS AND DISCUSSIONS}

The following are the findings of the interview. The data are presented based on the research questions.

\subsection{The students' view toward the implementation of online learning during Covid-19 outbreaks}

Regarding the undergraduate EFL students' view of the implementation of online learning during Covid-19 outbreaks, all participants come to an agreement that online learning from home is the best way to continue the teaching and learning process during pandemic. This is following government policy to encourage physical and social distance to prevent the spread of the coronavirus and protect its people from exposure to this virus. So, learning at home using internet is more safety than learning face to face on campus in the classroom.

In my point of view, the policy about implementing online learning during pandemic is good enough, because ready or not ready we must be ready to learn like this. So far, online learning is the best option during pandemic. (SN) It seems that online learning is a good choice for this situation. Study from home utilizing technology internet is more safety. (TT)

Based on the research findings, all the interviewed students acknowledged that learning online from home was a good choice at this time of the pandemic. They understood the circumstances where people were not allowed to gather in one place. They also supported government policy to study from home online with internet access to prevent the spread of the coronavirus.

\subsection{The challenging faced by undergraduate $E F L$ students in the implementation of online learning during the Covid-19 outbreaks}

Based on the findings of interview, the challenges faced by Indonesian undergraduate EFL students in the implementation of online learning during the pandemic can be divided into two levels, a) student problem b) 
lecturer problem. The participants reported that they have limited experience about online learning, also that they have limited or unstable internet connection. The majority of participants agreed that the implementation of online learning was not as effective as face-to-face learning in the classroom because of the numerous technical problems. They assumed that several lecturers did not have sufficient experience, knowledge and skills to use online learning method during the Covid-19 outbreak.

The problem I encountered during online learning was the unstable internet connection. Besides that, in my own opinion, the Zoom video call is less effective, because it is often distracted by the appearance of friends; faces and it often breaks down. To add more information, the data packet runs out quickly. (TT) It is very rare to find lectures who provide materials, however, there are a few who are diligent. Besides, online assignments are difficult, maybe it is because the lecturers think we have a lot of free time at home so we can do a lot of assignments without considering the long working hours. To be honest, sometimes we have our activities to pursue and it is unhealthy and impossible to always stay in front of a computer or phone because it takes family quality time too. (FQ)

The problem is lecturers sometimes give assignments to students anytime even when it is not their turn to deliver lessons. Due to this reason it becomes difficult to inter act and understand the lectures fully. For other classes, where lecturers use the Zoom application which allows video calls, and accommodates everyone, lessons are clear and easily delivered. For us the main problem is lecturer gives a lot of unexplained assignments. (RF)

In this study, the interviewed students shared the barriers to learning online from home. They stated that they experienced an unstable internet connection and expensive cost of internet packages. They think the Zoom application that the lecturer used in teaching is less effective because this application requires a stable signal. However, not all students are in an area that has a stable connection. It is different when they are on campus, they can access the high quality of internet connection provided by the university. Besides, utilizing Zoom consumes much data packet. On the contrary, one of the interviewed students argued that Zoom video calls can accommodate everyone; lessons are clear and easily delivered. Meanwhile, few of them spell out that WhatsApp also has proved to be less effective for video conferences due to its limited functions which cause communication between lectures and students were interrupted. In this case, both teachers and students must be able to maintain the signal stable.

Another problem is the lack of a fixed schedule. For instance, the lecturers sometimes gave assignments to students anytime even when it was not their turn to deliver lessons. Due to this reason, students must update every time because the tasks were many with deadlines at hand on Zoom, Edmodo, or WhatsApp platforms. As a result, it became difficult to interact with and understand the lectures fully. It became worst when some lecturers only gave assignments without explaining the learning material. Also, some lecturers send materials and assignment in form of PowerPoint presentation or file without delivering explanation to them, and even there were some lecturers did not give both. However, several lecturers opened discussion on the Whatsapp platform about the subject matter.

Numerous assignments and the implementation of a lecture unscheduled influenced students' health. Too many tasks given by the lectures spent much time to accomplish them. It is not healthy to always stay in front of a computer or smartphone. On another occasion, students should help their parents at home or spend quality time with their family.

\subsection{The benefits of the implementation of online learning during the Covid-19 outbreaks towards students' English language learning}

Online learning can be regarded as a solution to overcome physical distance in teaching and learning process [32]. Online learning enables the teachinglearning process to become more student-centered. It can be found in asynchronous learning in which students can learn anywhere, anytime, in any rhythm, with any means [7]. Hence, students were required to be responsible for their own learning. They asked to manage their own learning to complete the task given individually or collaboratively. It can be concluded that online learning requires student independence. Therefore, the steps in online learning can be used to promote student autonomy.

From my own experience during online classes, I answer assignments from my personal point of view. Researching the answer or topics by myself, without the influence of other students as answers or opinions will be totally different. I feel that the assignment is too much and hard to complete. So, we have to be smart to manage our time for many tasks since we need time to relax too. (FQ)

Because some lecturers only give online assignments, without explaining them clearly to us or they explain in a way that we don't understand. I would suggest to have access to ask questions directly through direct chat with lecturers discussing in the WhatsApp Class Group Chat. So even if, we might misunderstand some materials; we can discuss and learn the materials together other than doing it on our own. So, I think we should learn by our own or work together with others. (EC)

In this study, two interviewed students asserted that they have to manage their time to accomplish a lot of 
tasks given by the lecturer. They need a balance in time allocation between learning and relaxation. Therefore, they have to be autonomous learners in which they have self-initiative to learn independently at home during the emergency. Furthermore, since the lectures only sent the assignment without explaining them, sometimes it takes a long time to understand the materials. Learning autonomously or cooperatively with friends enables students to overcome that matter. Asking the lecturer directly through the WhatsApp group also suggested.

From the findings above, it is obvious that the EFL learners in Indonesia perceived implementing online learning is the best choice in the time of pandemic. In this situation, online learning is the best way and solution that we can implement for health reason where it is not possible for us to study face to face in the classroom [33]. To prevent the spread of Covid-19, many universities have to cancel face to face classes and move their class online. This decision should be administered to continue teaching and learning while keeping all their staff, lecturers and students safe from the virus. In line with Allo [34] reveals that online learning helps the students learning in the midst of COVID-19 pandemic. Since the current situation does not allow people to gather, online learning is considered more suitable and secure. Accordingly, students do not need to go to campus, hence study from home utilizing digital technology.

Along with the development of the industrial revolution 4.0, the best solution offered to continue the learning process during this pandemic is to carry out online learning using digital technology tools from their homes. Online learning has been echoed by Nadiem Makarim, the Ministry of Education and Culture, before the Covid-19 pandemic. This learning aims to make students technology literate, creative, highly motivated, independent, and innovative in facing the challenges of globalization. We are implementing online learning during COVID-19 outbreaks in line with the Ministry of Education and Culture programs.

The present study also reported two challenges that causing online learning was not as effective as offline learning. First, students have limited experience and skills in online learning, limited or unstable internet connection, and expensive cost of internet data packages. Although online learning is helpful and safe students' and faculty's health from exposure to the coronavirus disease. It is not effective in Pakistan as an underdeveloped country [8].

A majority of students in Pakistan are not able to access the internet due to technical and monetary issues. So, teachers need to check the students' readiness for online learning, whether they have had good facilities such as a personal computer, smartphone, and internet connection. Second, several lecturers have insufficient experience, knowledge, and skills to use online learning methods during the Covid-19 outbreak. For instance, some lecturers did not follow the schedule issue from the study program. As a result, the scheduled often clash. The lecturers, also often shared the material as well as assignment without giving explanations, and gave students too many assignments. The findings show that before the pandemic, students and teachers were not fully prepared to use online learning. Therefore, in this emergency, it is not easy for teachers to prepare their students to study online. In this case, teachers should identify the factors that affect the process of learning. So, they can take considered steps to solve problems that arise and improve the quality of learning [35]; [36].

Besides, this study contributes to the literature on barriers to the use of online learning during school closures. Indonesia as a developing country has experienced school closures and implementing online learning during the Covid-19 outbreaks.

In addition, online learning that is being experienced by Indonesian students today is one of Nadiem Makarim's dream called "Merdeka Belajar" or freedom to learn. It means that students learning independently. Students learn independently at home using technology tools in a synchronous or asynchronous setting, and the teacher plays his/her role as a facilitator. Therefore, online learning requires students to be independent or autonomous, creative, and innovative in learning to lead them to lifelong [7].

Besides, online learning is learning that utilizes technology, where students try to overcome several tasks and make decisions at any time. One of the goals of online learning is to maximize the decisions that students have made online by being given knowledge about correct answers and additional information that can be accessed at any time [37]. Thus, all students can learn autonomously at home online during the Covid-19 outbreaks and more familiar with ICT in their everyday life. As a result, they are ready to answer the demands of Education 4.0 and a disruptive era.

\section{CONCLUSION}

Based on the findings of the study above, EFL learners view that implementing online learning during COVID-19 outbreaks is the best choice to prevent the coronavirus from spreading further. However, in its implementation, online learning is not considered to be as effective as face-to-face learning. The technical and financial issue is the prominent barriers that students face. Meanwhile, from the lecturer's side, they have insufficient experience and knowledge about online learning. Learning online can be effective if it is well prepared and properly implemented such as shifting teaching methodologies, managing the time, and developing content that covers both curriculum and student's engagement. So, today is the best time for 
teachers to move from offline learning to online learning. Learning online using digital technology as promoted in Education 4.0 can help students learn autonomously. Students are able to manage their time for accomplish the assignment anywhere and anytime. In other words, online learning brings the flexibility aspect. The results of the study are hoped can stimulate further discussion in order to surmount online learning barriers by bearing in mind the importance of learners' voice.

\section{AUTHORS' CONTRIBUTIONS}

M, NSL, and YW contributed to design the research. M contributed to the implementation of the research $\mathrm{M}$, $\mathrm{DA}$, and $\mathrm{Y}$ contributed to the analysis, interpretation, and wrote the paper. NSL and YW supervised the research.

\section{ACKNOWLEDGMENTS}

We would like to thank the respondents who gave us valuable data for this research.

\section{REFERENCES}

[1] Almanthari, A., Maulina, S., \& Bruce, S., Secondary school mathematics teachers' views on e-learning implementation barriers during the covid-19 pandemic: the case of Indonesia, vol. 16, no. 7,2020 .

[2] Babayiğit, M. V., Cizrelioğullari, M. N., \& Altun, Ö, How does online learning facilitate teaching? is it a new phenomenon or due to coronavirus? a collection of students' views. ECLSS Online 210 2020.

[3] Priyadarshini, A., \& Bhaumik, R, E-readiness of Senior School Learners to Online Learning Transition amid COVID-19 Lockdown. Asian Journal of Distance Education, vol. 15, no. 1, 2020, pp. 244-256.

[4] Hodges, C., Moore, S., Lockee, B., Trust, T., \& Bond, A, The difference between emergency remote teaching and online learning. Educause Review, 27, 2020.

[5] Zaharah, Z., Kirilova, G. I., \& Windarti, A, Impact of corona virus outbreak towards teaching and learning activities in indonesia. salam: Jurnal Sosial Dan Budaya Syar-I, vol. 7, no. 3, 2020, pp., 269-282.

[6] Rajab, M., Gazal, A., \& Alkattan, K, Challenges to Online Medical Education During the COVID-19 Pandemic. Cureus, vol. 12, no. 7, 2020. DOI: https://doi.org/10.7759/cureus.8966
[7] Dhawan, S, Online learning: a panacea in the time of covid-19 crisis. Journal of Educational Technology Systems, vol. 49, no. 1, 2020, pp. 5-22. DOI: https://doi.org/10.1177/0047239520934018

[8] Adnan, M., \& Anwar, K, Online learning amid the covid-19 pandemic: students' perspectives. Journal of Pedagogical Sociology and Psychology, vol. 2, no. 1, 2020, pp.45-51.

[9] Rasmitadila, R., Aliyyah, R. R., Rachmadtullah, R., Samsudin, A., Syaodih, E., Nurtanto, M., \& Tambunan, A. R. S. The perceptions of primary school teachers of online learning during the covid19 pandemic period: a case study in indonesia. Journal of Ethnic and Cultural Studies, 7(2) 2020, pp. 90. DOI: https://doi.org/10.29333/ejecs/388

[10] Irfan, M., Kusumaningrum, B., Yulia, Y., \& Widodo, S. A, Challenges during the pandemic: use of e-learning in mathematics learning in higher education. Infinity Journal, 9 (2) 2020.

[11] Famularsih, S, Students' Experiences in using online learning applications due to covid-19 in english classroom. Studies in Learning and Teaching, 1 (2) 2020, pp. 112-121.

[12] Allen, I. E., \& Seaman, J, Staying the course: Online education in the United States, ERIC, 2008.

[13] Keengwe, J., \& Kidd, T, Towards best practices in online learning and teaching in higher education. Journal of Online Learning and Teaching, 6 (2) 2010, pp. 533-541. DOI: https://doi.org/http://dx.doi.org/10.1108/17506200 710779521

[14] Kruger-Ross, M. J., \& Waters, R. D, Predicting online learning success: applying the situational theory of publics to the virtual classroom. Computers \& Education, 61, 2013, pp. 176-184.

[15] Sun, A., \& Chen, X. (2016). Online education and its effective practice: a research review. Journal of Information Technology Education: Research, 15 2016, pp. 157-190. DOI: https://doi.org/10.28945/3502

[16] Allen, I. E., \& Seaman, J, Changing course: ten years of tracking online education in the United States, ERIC, 2013.

[17] Hannay, M., \& Newvine, T, Perceptions of distance learning: a comparison of online and traditional learning. Journal of Online Learning and Teaching, vol. 2, no. 1, 2006, pp. 1-11.

[18] Solimeno, A., Mebane, M. E., Tomai, M., \& Francescato, D. The influence of students and teachers characteristics on the efficacy of face-to- 
face and computer supported collaborative learning. Computers \& Education, vol. 51, no. 1 2008, 109-128.

[19] Campbell, L. What does the "e" stand for. Melbourne: thesis, Department of Science and Mathematics Education. The University of Melbourne, 2004.

[20] Suherdi, D, Teaching english in the industry 4.0 and disruption era: early lessons from the implementation of smelt i 4.0 de in a senior high lab school class. Indonesian Journal of Applied Linguistics, vol. 9, no. 1, 2019, pp. 67-75. DOI: https://doi.org/10.17509/ijal.v9i1.16418

[21] Abdulrahim, H., \& Mabrouk, F, COVID-19 and the digital transformation of saudi higher education. Asian Journal of Distance Education, vol. 15, no. 1, 2020, pp. 291-306.

[22] Bozkurt, A., \& Sharma, R. C, Emergency remote teaching in a time of global crisis due to CoronaVirus pandemic. Asian Journal of Distance Education, vol. 15, no. 1, 2020, pp. i-vi.

[23] Quintana, R., \& Quintana, C, When classroom interactions have to go online: the move to specifications grading in a project-based design course. Information and Learning Science, 121(78) 2020, pp. 525-532, DOI: https://doi.org/10.1108/ILS-04-2020-0119

[24] Putra, R. S., \& Irwansyah, I. Media komunikasi digital, efektif namun tidak efisien, studi media richness theory dalam pembelajaran jarak jauh berbasis teknologi di masa pandemi. global komunika: Jurnal Ilmu Sosial Dan Ilmu Politik, vol. 1, no. 2, 2020, pp. 1-13.

[25] Lestari, P. A. S., \& Gunawan, G, The impact of covid-19 pandemic on learning implementation of primary and secondary school levels. Indonesian Journal of Elementary and Childhood Education, vol. 1, no. 2, 2020, pp. 58-63.

[26] Hadijah, S., \& Shalawati, S, Investigating teachers' barriers to ict (information communication technology integration in teaching english at senior high schools. Proceeding of the Fifth International Seminar on English Language Teaching (ISELT5), 2017, pp. 302-310.. DOI: http://ejournal.unp.ac.id/index.php/selt/article/view /8019/6121

[27] Quadri, N. N., Muhammed, A., Sanober, S., Qureshi, M. R. N., \& Shah, A, Barriers effecting successful implementation of e-learning in Saudi Arabian Universities. International Journal of
Emerging Technologies in Learning (IJET), vol. 12, no. 06, 2017, pp. 94-107.

[28] Assareh, A., \& Hosseini Bidokht, M, Barriers to eteaching and e-learning. Procedia Computer Science, 3, 2011, pp. 791-795. DOI: https://doi.org/10.1016/j.procs.2010.12.129

[29] Creswell, J. W. Educational research: planning, conducting, and evaluating quantitative and qualitative research. In Pearson Education, Inc. Boston, 2012.

[30] Fraenkel, J. R., Wallen, N. E., \& Hyun, H. H, How to design and evaluate research in education, McGraw-Hill, New York, 2011.

[31] Braun, V., \& Clarke, V, Using thematic analysis in psychology. Qualitative Research in Psychology, vol. 3, no. 2, 2006, pp. 77-101.

[32] Haron, N. N., Zaid, Y. H., \& Ibrahim, N. O, Elearning as a platform to learn english among esl learners: benefits and barriers. Research in Language Teaching and Learning, 7 2015, pp. 79105.

[33] Ahmady, S., Shahbazi, S., \& Heidari, M, Transition to virtual learning during COVID-19 crisis in Iran: opportunity or challenge. Disaster Medicine and Public Health Preparedness, 2020, pp. 1-3.

[34] Allo, M. D. G. Is the online learning good in the midst of Covid-19 Pandemic? The case of EFL learners. Jurnal Sinestesia, vol. 10, no. 1, 2020, pp. $1-10$.

[35] Mann, S., \& Walsh, S. Reflective Practice In English Language Teaching: Research-Based Principles And Practices. Taylor \& Francis, 2017.

[36] Richards, J. C., \& Rodgers, T. S, Approaches And Methods In Language Teaching. Cambridge university pres, 2014.

[37] Hoi, S. C. H., Sahoo, D., Lu, J., \& Zhao, P. Online learning: a comprehensive survey. arxiv preprint arxiv:1802.02871. e.m. clarke, e.a. emerson, design and synthesis of synchronization skeletons using branching time temporal logic, in: d. kozen (eds.), workshop on logics of programs, Lecture Notes in Computer Science, Springer, Berlin, Heidelberg, vol. 131 2018, pp. 52-71. DOI: https://doi.org/10.1007/BFb0025774 